\title{
ENKELE OPMERKINGEN OVER SURINAAMSCHE MUZIEK
}

\author{
DOOR \\ ARY SCHIPPER
}

In dit artikel wenschen wij geen Europeesche muziek in Suriname te behandelen, en evenmin den invloed, die Europeesche muziek, in meer of minder mate op Surinaamsche inheemsche muziek heeft uitgeoefend. Ook de Indiaansche muziek laten wij hier buiten beschouwing. Maar wij roepen de aandacht in voor die primitieve muziek in Suriname, die onder Afrikaanschen invloed staat. Dat is - algeheel (voor zoover is na te gaan) - de eigenlijke Boschnegermuziek, en voor een belangrijk deel, de muziek, die beoefend wordt door gekleurden, door negers en kleurlingen in de stad en in de districten en die geheel of gedeeltelijk van Afrikaansch bloed zijn. De wijsjes en deunen, de liederen en de muziek van Europeeschen oorsprong van die gekleurden in het beschaafde gedeelte van Suriname, zijn dus mede bij onze beschouwingen uitgesloten.

De studie van de Surinaamsche muziek is, zoowel uit musicologisch als uit ethnologisch oogpunt, zeer belangrijk. Tevens is zij van groote beteekenis voor het maken van een vergelijkende studie van de verschillende muzikale stijlen der Afrikaansche rassen, welke studie op haar beurt weer opheldering kan geven over sommige belangrijke cultureele problemen.

Typen van Surinaamsche muziek, bij ons vooral bekend, zijn „,jazz” en ,,spirituals”. Andere typen zijn, helaas, nog weinig bestudeerd.

Hoewel wij zelfs in de verste verte geen vergelijkingen mogen en kunnen maken tusschen de muziek der Chineezen en die der Surinaamsche Negers, trof het mij toch toen ik bemerkte, dat zoowel de Chineesche als de Surinaamsche muziek pentatonische en heptatonische reeksen kent. Zooals men weet, was de oorspronkelijke Chineesche toonladder pentatonisch, d.w.z. zij bestond uit 
vijf verschillende tonen, $n .1 .: f-g-a-c-d-f$. Deze toonladder bevatte, zooals wij zien, geen halve toonafstanden, waarom men haar ook anhemitonisch noemt. Een voorbeeld van een oorspronkelijke Chineesche melodie, gebouwd op zulk een pentatonische scala, vinden wij in de ouverture ,Turandot" van Weber. Later ( \pm 1200 v. Chr.) werden de $e$ en $b$ toegevoegd. Deze tot zeven tonen vermeerderde toonladder, die nu dus wel halve toonafstanden bevatte (n.l. e-f en b-c), noemt men heptatonisch. Ook de Surinaamsche muziek kent anhemitonische en heptatonische reeksen en, behalve deze, ook hexatonische. Deze laatste zijn in de meeste gevallen eigenlijk niets anders dan een uitbreiding van pentatonische reeksen (n.l. van 5 tot 6 tonen). Een voorbeeld van zulk een Surinaamsche anhemitonisch-pentatonische-ladder is bijvoorbeeld de reeks $\mathrm{c}-\mathrm{d}-\mathrm{e}-\mathrm{g}-\mathrm{a}-\mathrm{c}$.

\section{De liederen der Boschnegers.}

Bestudeert men den omvang der liederen, dan bemerkt men, dat deze zeer verschillend is van tonale structuur. Behalve, dat een groot aantal liederen bestaat uit intervallen van slechts een terts of kwart, zijn er sommige met een omvang van meer dan $11 / 2$ octaaf. Overheerschend is het aantal van grooten omvang. Veertig procent blijven binnen de grenzen van een terts tot een septiem, terwijl zestig procent een omvang hebben van een octaaf en meer. De omvang van een groote sext komt het meest voor, die van een kleine sext zeldzaam. Bij liederen van grooten toonomvang reiken de grenzen dikwijls tot de groote decime, groote none of octaaf.

De betrekkelijke gelijkluidendheid van de intervallen is klaarblijkelijk de oorzaak waardoor wij slechts een klein aantal liederen vinden met een omvang van een groote septiem en een kleine none en niet één met een omvang van een vermeerderde kwart.

Bij het meerendeel der Surinaamsche zangen is de melodie dalend. Daardoor is het niet te verwonderen, wanneer wij bijvoorbeeld melodieën tegenkomen waarvan de laagste noot meer dan een sext lager is dan de begintoon. Dergelijke melodieën komen meer voor $(29 \%)$ dan die, waarvan de hoogste noot meer dan een sext hooger ligt dan de beginnoot $(9 \%)$.

Het in het oog loopend herhaalde gebruik van groote toontrappen geeft aan de melodische lijn een exentrieken en eenigszins primitieven vorm. Bijna alle liederen $(91 \%)$ bevatten intervallen van een kwart of meer. De stijgende of dalende kwart komt veel voor $(85 \%)$. De kwint daarentegen niet zoo veel $(45 \%)$ en 
is dan meer een dalende $(31 \%)$ dan een stijgende $(20 \%)$. Zelden ontmoeten wij nog grootere intervalssprongen, zooals de kleine sext $(9 \%)$, groote sext $(2 \%)$ en - bijna steeds dalend - het octaaf-interval $(6 \%)$. Ook vinden wij recitatieven, als gedeelten van een lied, gezongen op dezelfde hoogte. Kleine uitgebreide herhalingen van een enkelen toon komen zeer veel voor. In verreweg het grootste gedeelte der liederen $(70 \%)$ vindt men zinnen, waarin vier of meer lettergrepen op dezelfde noot worden gezongen.

Een speciale karaktertrek van de Boschnegermuziek is de verbinding van terts-intervallen. Hierbij kunnen drie typen worden onderscheiden:

1: de pendel-beweging;

2: het opeenvolgen van tertsen, die in dezelfde richting gaan;

3: het in elkaar sluiten of ,haken" van tertsen.

De ,pendel-beweging" is bijvoorbeeld de melodische figuur $\mathrm{a}-\mathrm{c}-\mathrm{a}-\mathrm{c}$ of $\mathrm{c}-\mathrm{a}-\mathrm{c}-\mathrm{a}$ :

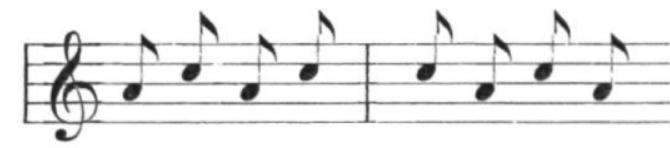

Herhalingen van denzelfden toon kunnen eigenlijk geen ,,toontrappen" worden genoemd; daarom moet een melodische vorm als bijvoorbeeld onderstaand motief, waarbij een der beide hoektonen van het pendel-type zich meermalen achtereen doet hooren, steeds worden beschouwd als een aaneenschakeling van tertsen:

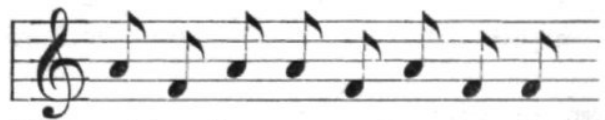

Zulke ,pendel” combinaties van minstens drie opeenvolgende kleine of groote tertsen - met of zonder herhalingen van denzelfden noot - vinden wij bij iets minder dan de helft der liederen.

Het tweede type bestaat, zooals wij zagen, uit een opeenvolging van tertsen, die in dezelfde richting gaan. Bijvoorbeeld:

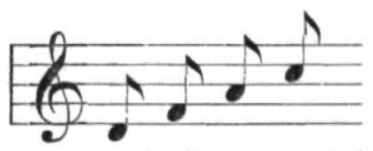

Twee kleine tertsen, vereenigd tot een tritoon, vormen een dissoneerend- en een kleine en groote terts een consoneerend interval (kwint). Dergelijke opeenvolgingen van tertsen, die den Europeaan den indruk geven van gebroken mineur- en majeur-tertsen, komen veelvuldig in de muziek der primitieven voor. Dit type 
moet, daar de Surinaamsche muziek geen accoorden in onze beteekenis kent, slechts als streng melodisch worden opgevat.

Onder het derde type, de z.g.n. ,"hakende” of in elkaar sluitende tertsen, verstaan wij terts-intervallen, óók gaande in dezelfde richting, die met de volgende tertsen zijn verbonden door middel van bovenseconden.

Bijvoorbeeld:

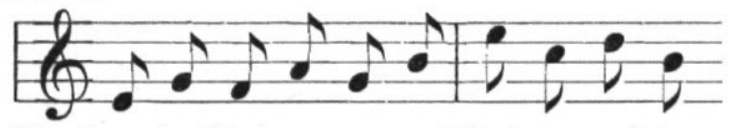

Gewoonlijk komt dit type voor bij twee achtereenvolgende tertsen, zelden bij drie, en is dan in den regel dalend.

Dezelfde typen vinden wij ook bij de kwart-intervallen.

Wat wij bij het „,pendeltype” over toonherhalingen opmerkten, geldt ook voor de beide andere typen.

„De drie typen van tertsverbinding - schrijft Gilbert 1) vinden wij ook in andere negroïde muziek. In dit verschijnsel ligt o.i. een van de voornaamste aanleidingen voor de hierboven geconstateerde toenadering van de Negermelodie tot de Europeesche harmonie. Want onze accoorden zijn meestal slechts de samenklank van op elkaar gestapelde terts-schreden; ook ons accoord wordt door terts-intervallen gedomineerd. Vervolgens wezen wij er reeds op, dat het schakeltype onder de terts-figuren op ons den indruk van een ,gebroken accoord" maakt. De blanke vat zulke negermelodie-vormen dus gemakkelijk accoordisch (harmonisch) op en omgekeerd verstaan de negers ons ,"gebroken accoord" licht als pure melodie. Ziehier een belangrijk punt voor contact."

Volgens sommige schrijvers is de muziek in haar oervormen verwant aan de melodie van het gesproken woord. Is dit zoo, dan verbaast het ons niet, wanneer wij de primitieve Negermelodieën gebouwd zien op aan deze spraakmelodie ontleende tonen. Immers, ook de spraak heeft haar eigen toonhoogte, wat merkbaar is bij stemverheffing en -daling. Men heeft de spraakmelodie van Noord-Amerikaansche Negers bestudeerd en hierbij bleek, dat een drietonige melodie de spraak beheerschte, n.l.:

1) de normale spreektoon, die wel het meest voorkomt;

2) bij stemverheffing de toon liggende een groote seconde boven den normalen spreektoon, en

3) bij stemdaling - zooals deze bij toonlooze lettergrepen, einde van zinnen en ook wel bij sombere stemmingen wordt ge-

1) Will G. Gilbert, blz. 15. 
bezigd - de toon liggende een kleine terts onder den normalen spreektoon.

Bijvoorbeeld:

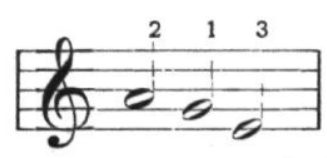

Deze drie toonhoogten vormen een hechte combinatie en wel in dien zin, dat de onderlinge afstand tusschen de toonhoogten steeds dezelfde blijft. In deze vereeniging zijn zij evenwel niet aan een vaste toonhoogte gebonden, daar de één laag, de ander hoog en de derde weer op normale hoogte spreekt. Deze drie aan de spraakmelodie ontleende tonen liggen - wij schreven het reeds - ten grondslag aan de Surinaamsche melodieën. ,Wij vinden zegt Gilbert - deze melodiekernen als opvallende bestanddeelen van Afrikaansche en Afro-Amerikaansche melodieën terug, ja, volslagen muzikale phrasen maken soms uitsluitend van deze drie kerntonen gebruik. Soms treffen wij in één melodie twee van deze kernen op verschillend toonhoogte-niveau aan; de melodie omcirkelt dan als het ware afwisselend de door de kernen aangegeven zone, doch zij springt niet klakkeloos van de eene kern in de andere." 1 ).

Bijna de helft der liederen past, zonder dat men hun inhoud geweld aandoet, in een metrisch schema. Even maatsoorten komen meer voor dan oneven. In de meeste liederen is een veelvuldig gebruik gemaakt van triolen. Bij de oneven maten komt de driekwartsmaat het meest voor, terwijl ook de vijfkwarts- en zevenkwartsmaat tegenwoordig zijn.

$\mathrm{Nu}$ en dan is de maat verlengd of verkort of wij treffen in den loop van het lied een verandering van rhythme aan. In andere liederen zijn weer verschillende maten vereenigd in een geregelde of gevariëerde opeenvolging. Deze vrijheden ten spijt vertoonen de liederen een streng rhythmisch karakter. Slechts een derde deel heeft een vrij rhythme, dat zelfs in die vrijheid een zekere verbondenheid met het spraakrhythme vertoont, wat ons, na hetgeen wij reeds over de spraakmelodie schreven, niet vreemd meer zal toeschijnen.

De liederen worden dikwijls begeleid door tromslagen of door handgeklap. In de meeste gevallen beteekent dit alleen een accentueering van het melodisch rhythme. De begeleidende maatslagen

1) Will G. Gilbert, blz. 15. 
bestaan in den regel uit gewone kwartnoten. In sommige liederen zijn de kwartslagen verdeeld in twee achtste noten, in andere in triolen elk van $3 / 8$ noten. In enkele liederen wordt de $6 / 8$ maat geaccentueerd door regelmatige $3 / 8$ tromslagen, terwijl weer in andere de begeleiding sterk verschilt van het melodisch rhythme. Trom-rhythme in vivacissimo tempo, dat evenwel, ondanks zijn levendigheid, nog een voortdurende eenheid vormt met het rhythme der liederen, komt eveneens voọr.

Dat sommige liederen, die zich kenmerken door een meer of minder vrij rhythme, worden begeleid in een strenge $3 / 8$ maat is zeker merkwaardig. Bij de Surinaamsche muziek kunnen wij dus spreken van poly-rhythmiek.

Behalve op pentatonische, heptatonische en andere reeksen, die wij reeds in den aanvang van dit artikel leerden kennen, is de Surinaamsche muziek ook nog gebaseerd op toonreeksen, die wel met onze majeur- en mineur- toonladders overeenkomen, doch waarin de toonconstructie sterk van onze theorieën afwijkt.

Gelijkzwevende temperatuur, zooals wij die kennen, is den Neger onbekend, althans hij huldigt een geheel andere ,,muziektheorie". Buiten halve toonafstanden zingt hij ook nog kwart- en driekwarttonen en glijdt hij met zijn stem in sterk portamento van de eene toonhoogte in de andere. ,,De systeemlooze toonverglijdingen herinneren ons aan den oerovergang van spreektoon naar muzikalen zangtoon, van lukrake toonhoogten naar vaste laddertonen." (Gilbert)

Het gebruik van de falcet-stem komt weinig voor. De inhoud der liederen toont ons, dat de falcet-stem haar ontstaan dankt aan een weloverwogen en bewust gebruik van hoofdtonen.

Over het algemeen is het tempo tamelijk levendig. In de meeste gevallen $(91 \%)$ blijft het constant. Soms evenwel wordt het, terwijl de melodie voorschrijdt, versneld.

Beschreven wij hierboven in korte trekken de muziek der Boschnegers, thans willen wij die der Creolen eens nader bezien.

Ook hun liederen vertoonen een aanmerkelijk verschil in toonomvang. In de stadsliederen wordt bij $6 \%$ een omvang van meer dan een kleine decime gevonden (boschliederen 29\%). Het meest gebruikelijk is de toonomvang van een octaaf.

De neiging tot dalen is bij de liederen der Creolen zeer sterk. Ongeveer $20 \%$ begint met de hoogste noot van het lied (boschliederen $8 \%$ ), terwijl $27 \%$ meer dan een kwart boven den openings- 
toon stijgt (boschliederen $42 \%$ ), en een maximum hoeveelheid van meer dan een kwart beneden den openingstoon wordt gevonden $(62 \%)$ (boschliederen 56\%).

Slechts 10\% van de stadsliederen (boschliederen 63\%) zijn geheel of bijna geheel zonder halve toonafstanden. De volgende tabel geeft een vergelijkend overzicht van het gebruik van intervallen bij Stads- en Boschliederen:

$\begin{array}{lrc} & \text { Stad } & \text { Bosch } \\ \text { Kwartintervallen } & 62 \% & 85 \% \\ \text { Kwintintervallen } & 18 \% & 45 \% \\ \text { Sextintervallen } & 8 \% & 11 \% \\ \text { Octaafintervallen } & 1 \% & 6 \%\end{array}$

Veelvuldige toonherhalingen komen, evenals in boschliederen, zeer veel voor. Twee derden der stadsliederen bevat deelen, waarin vier of meer lettergrepen op dezelfde toonhoogte worden gezongen.

In stadsliederen komt de vierkwartsmaat het meest voor, terwijl de $3 / 4$-maat zeldzaam is. De $6 / 8$-maat komt meer voor dan de 5/4-maat. Maatverlengingen en samentrekkingen van maat zijn zeer in zwang. Bijvoorbeeld de $4 / 4$ maat wordt verkort tot $7 / 8$ of tot $3 / 4$, of uitgebreid tot $5 / 4$. Deze veranderingen worden ten deele veroorzaakt door den zin van den tekst. Voor een aantal liederen kan geen streng metrisch schema worden opgesteld, niettegenstaande het feit, dat een geregelde maat kan worden herkend, als grondslag van een rhythmischen vorm. Verschillende teksten zijn bij bepaalde gelegenheden op eenzelfde melodie getoonzet, waardoor de maat nog wel eens aan verandering onderhevig is. Liederen in een vrij rhythme komen in de stadsmuziek minder voor dan in die van het bosch.

In vele gevallen versnelt het tempo gedurende de voortschrijding der melodie. Herhalingen door het koor worden bij sommige gelegenheden sneller en bij andere weer langzamer gezongen.

\section{De muziekinstrumenten.}

In de Surinaamsche muziek, die zoowel poëzie als zang en zoowel zang als dans is, spelen de slag- en ratelinstrumenten een voorname rol. Ik wil hier echter direct aan toevoegen, dat de Negers deze instrumenten ook wel als bezweringswerktuigen aanwenden, wat, gezien de magische kracht, die zij aan de muziek toeschrijven, geen verwondering baart. 
Onder de slaginstrumenten nemen de trommen, die zij van uitgeholde boomstammen vervaardigen, de voornaamste plaats in. Er zijn verschillende tromtypen, die, naar gelang van den aard van den dans, afwisselend worden gebruikt. Bij de Boschnegers heeft men de ,apienti”, — de ,toemao" - en de ,,agida” trommen 1). De Creolen kennen er zelfs vijf, n.l. de „,apienti”, de ,podja”, de ,mandrom", de ,langadrom" en de ,agida” (zie afbeelding). De „podja”' gelijkt zeer veel op de ,apienti”. Voor het bespelen van de trommen, zooals de ,,apienti” en de „toemao", gaat de muzikant schrijlings op de trom zitten, die met het vooreinde op de hielen van den speler of op een blok rust, waardoor een grooter klankvolume wordt bereikt dan wanneer de trom op den grond staat. Het tromgeluid klinkt, vooral des nachts, uren ver in den omtrek 2), en men denke nu niet, dat de Neger alleen maar tromslagen hoort. Hij hoort veel meer. Want volgens zijn opvatting spreken de stemmen zijner voorouders en goden door de trommen! Vooral de ,apienti" is hiervoor het aangewezen instrument en de op haar geslagen rhythmen zijn dan ook het gecompliceerdst.

Gilbert zegt, dat zij de eenige is, die met snijwerk is versierd en die de gewijde membraanbevestiging heeft, welke direct van de Afrikaansche Goudkust afkomstig schijnt te zijn. ,,Deze tromvelbevestiging - vervolgt hij - bestaat uit een samenstel van koorden en houten pennen, die in den tromwand gedreven zijn; door het aanslaan van deze pennen spant men het vlies. Geen boschneger zal met een van de andere trommen genoegen nemen voor het slaan van een ,apienti"'-rhythme: liever improviseert hij een ,apienti" uit het eerste materiaal het beste. De „toemao”, de middelste in afmeting, en de ,agida”, de grootste, die het grondrhythme aangeeft, zijn niet zoozeer met dit waas van wijding omgeven en het is dan ook frappant, dat zij een membraanbevestiging zonder pennen bezitten; zij doen het af met touw„bretels", waartusschen ter versteviging en voor de spanning enkele wigvormige latten zijn gestoken" ${ }^{3}$ ).

Ook de ,agida"-trom is in de oogen der Negers een zeer belangrijk instrument, want zij roept de aardgoden op en slaat het grondrhythme der dansen.

1) De „toemao"-trom is speciaal aan de Apoekoe of boschgeesten gewijd.

2) H. C. Focke, blz. 96

3) Will G. Gilbert, p. 11. Hetzelfde verhaalt ook Dr. Kolinski (blz. $521)$ 
Uit: W. G. Gilbert, Negr. muziek.

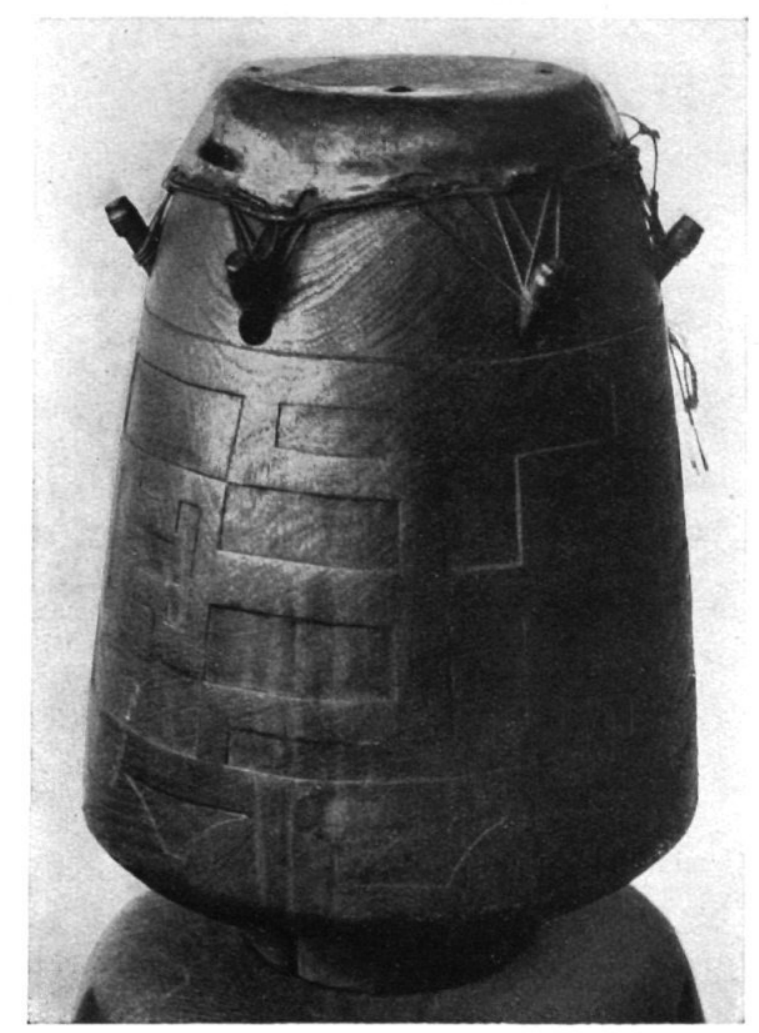

Jhr. L. C. van Panhuys schonk, naar hij mij mededeelde, deze "Apienti"-trom aan het Kol. Instituut. De hoogte bedraagt $511 \frac{1}{2} \mathrm{~cm}$. en de middellijn van het tromvel $20 \mathrm{~cm}$. 
Uit: W. G. Gilbert, Negroïde muziek.

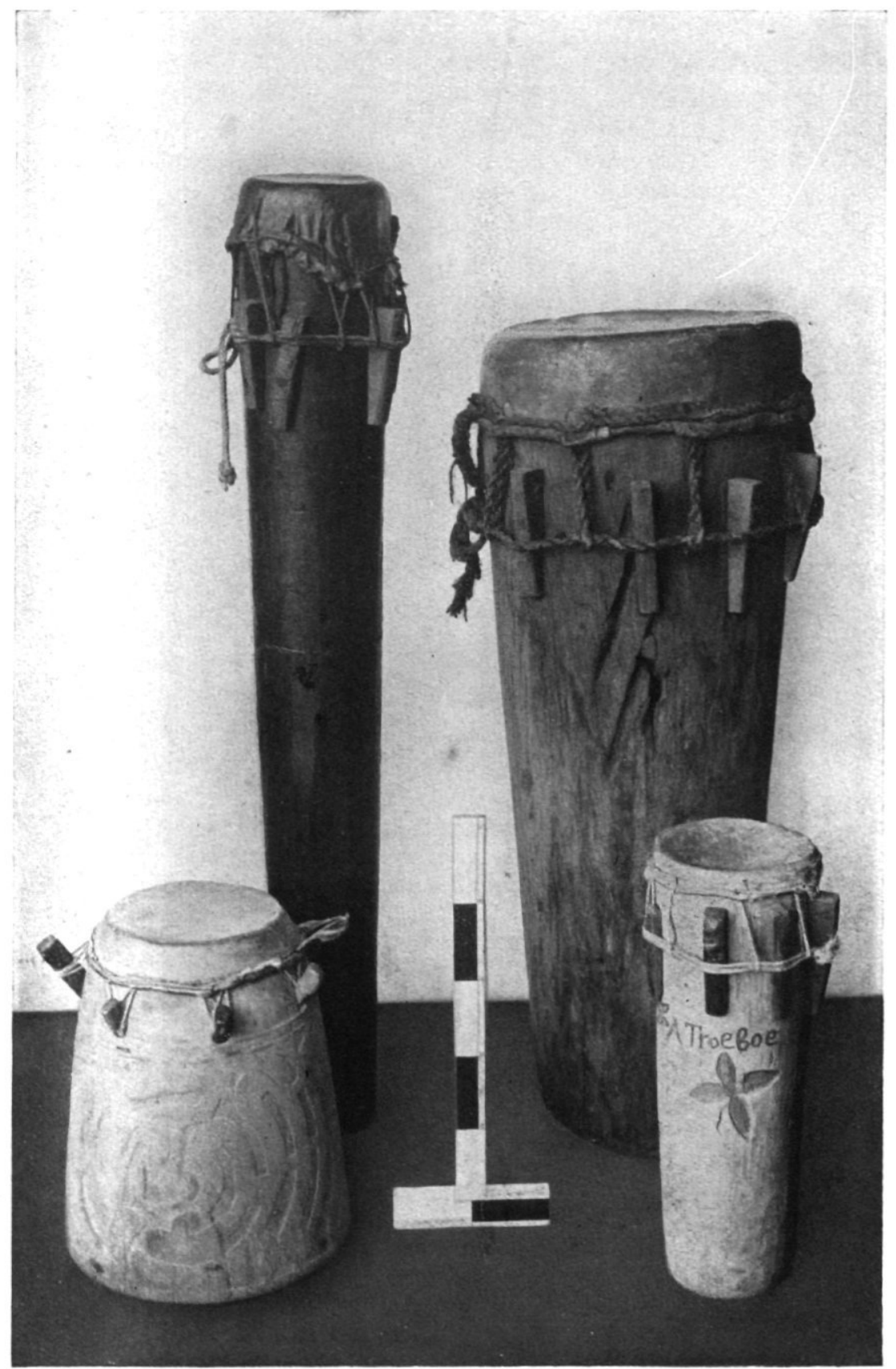

Riturele trommen voor de ,Winti"'-dansen. V.l.n.r. ,Apienti” „Langa drom”, ,Agida” en ,Mandrom”. 
Naast de hierboven genoemde trommen bespeelt de Neger ook nog de ,kreole” en de „kauna”- of „kawine”-trom, beide nietritueele danstrommen, aan beide zijden met een vel bespannen.

Teenstra schrijft zoo aardig, als hij het over de groote trommen in het algemeen heeft: „Verliest dit schoone instrument onder het spelen deszelfs toon, dan gieten zij er aan de achterzijde dram ${ }^{1}$ ) in, zeggende: da trom no wanni wakka boen, wi za gi em wan soopie! dat is: de trom wil nog niet regt aan den gang, wij zullen hem een zoopje geven" ${ }^{2}$ ).

De trommen kunnen twee verschillende tonen laten hooren. Slaat men n.l. op het midden van het over de trom gespannen vel, dan hoort men den grondtoon, terwijl bij het op den rand slaan de terts wordt gehoord.

Nooit mogen de trommen door vrouwen worden bespeeld of zelfs maar door haar worden aangeraakt, want men gelooft stellig, dat dan haar borsten zoodanig gaan groeien, dat ze den grond raken. De mannen zijn ware virtuozen in het bespelen van de trommen. Blinkt men hierin uit, dan is dit toe te schrijven aan de gunst der goden. „Hij heeft machtige goden”, zeggen de Boschnegers en in de stad heet het: „Het is zijn winti”, d.w.z. zijn eigen god, wien hij persoonlijk is toegewijd en die zich bij tijden door hem manifesteert.

Vóór de dansen aanvangen, kan men dikwijls kleine jongens bezig zien met het bespelen van de trommen, terwijl meisjes op de maat ervan dansen en de ouderen ernaar luisteren, onderwijl de fouten verbeterende.

$\mathrm{Na}$ de trommels volgen de rammelaars als de belangrijkste der hulpinstrumenten. Zij zijn onmisbaar voor elke religieuze ceremonie en in staat de geesten op te roepen Men kent o.m. de JurriJurri en de Sakka-Sakka.

De Jurri-Jurri is een kastanjebruine noot (Cerbera ahorai Linneus), waarvan de schalen aan elkaar worden geregen om zoo als rammelaar te worden gebezigd.

De Sakka-Sakka is een eivormige kalebasschaal, iets grooter dan een ganzenei, voorzien van een steel. Deze schaal is gevuld met de zoogenaamde Sakka-Sierie, dit zijn zwarte, gladde boontjes, ter grootte van duivenboonen. Soms zijn deze Sakka-Sakka's fraai beschilderd en Teenstra zag er zelfs, die enkel uit zilver bestonden $\left.{ }^{3}\right)$.

1) Dram is een soort rum.

2) R. D. Teenstra, 2e dl, blz. 192-3.

3) Teenstra, blz. 191 
Focke spreekt nog van de Joro-Joro, ,,een snoer van door midden gespletene en aan elkander geregene schalen van de vrucht der Thevetia neriifolia" 1 ).

Vervolgens noemen wij hier de Kwa-kwa, een lage bank van hard hout, waarop met twee stokjes (kwa-kwa tikie) het grondrhythme wordt geslagen. De Boschnegers nemen - volgens Dr. Kolinski - voor dit doel ook genoegen met een oude houten kist en twee stukken hout 2). De naam ,,kwa-kwa” zou dit instrument te danken hebben aan het feit, dat, volgens de Negers, het op haar voortgebrachte geluid veel overeenkomst vertoont met het gekwaak van een eend ${ }^{3}$ ).

Verder gebruikt men nog een geïmproviseerde triangel van tegen elkander geslagen stukjes ijzer (feloe-kum-feloe?), eenige tokkelinstrumenten van Europeeschen en Afrikaanschen oorsprong en - volgens Dr. Serrurier - een verbeterden vorm van de fluit der Indianen, een paar soorten van trompetten, die op Afrikaansche wijze op zijde geblazen worden en, zonderling genoeg, de neusfluit en de schelptrompet 4).

„Van verre raast de muziek van dit orkest gelijk een brommende honigbij onder den hoed", merkt Teenstra zeer aardig op s).

Tenslotte nog slechts enkele woorden over de Negerdansen, dansliederen en andere niet-ritueele zangen.

We schreven reeds, dat de Surinaamsche muziek zoowel poëzie als zang en zoowel zang als dans is. „De neger - zegt Focke huldigt drie Muzen te gelijker tijd". Doch deze drie danken hun ontstaan aan het religieuze leven van den Neger, dat wordt samengevat in het begrip ,Winti”, een geloof aan goden en geesten van gestorvenen. Deze religie heeft een eeredienst, bestaande uit ritueele dansen, het zingen van dansliederen en het bespelen van heilige muziekinstrumenten.

Tot de voornaamste ritueele dansen behooren de Winti-dansen. Hierbij zijn de drie aanzienlijkste muziekinstrumenten, n.l. de trommen, de Kwa-Kwa en de Sakka-Sakka in gebruik. Onder leiding van een Wintiman worden bij de Boschnegers, zoo dikwijls ,,als de goden dit vragen", en bij de Creolen, bij speciale gelegenheden, in het openbaar en in groepen de dansen uitgevoerd.

De teksten der ritueele dansliederen hebben in den regel tot

1) Focke, blz. 94

2) Kolinski, blz. 522 .

3) Teenstra, blz. 192

4) Catalogus, blz. 296

s) Teenstra, blz. 193 . 
inhoud het oproepen van de goden en goddelijke voorouders. Vooral bekend is de godin „Gron-mama” of aardmoeder, ook bekend onder den naam „Dagowe”, de god „Lebba” en verder de „Kromanti”, een speciale groep van goddelijke voorouders.

Onder de niet-ritueele liederen vinden wij arbeids- en dansliederen. Van deze laatste zijn vooral bij de Boschnegers bekend de „Seketi"'-, „,Awasa- en „,Soesa"-dansliederen, terwijl onder de Creolen de „Kauna”- of „Kawina”-dansliederen populair zijn. Verder zijn bekend de „Lobi singi”, het satirische liefdeslied, de „Banja”, de „Doe” en gezelschapsliederen onder den verzamelnaam „Anansi tori".

En hiermede zijn de onderwerpen van Surinaamsche dansen en liederen nog slechts even aangeroerd! De studie van deze muziek - merkte eenige jaren geleden terecht een medewerker aan de Encyclopaedie van Nederlandsch-West-Indië op - staat nog in haar kinderschoenen!

\section{LITTERATUUR.}

1. Gids in het Volkenkundig Museum.

2. Melville J. Herskovits and Frances S. Herskovits, ,,Suriname folklore. Part III, Suriname music by Dr. M. Kolinski". Columbia University contributions to Anthropology, Vol. XXVII, New-York 1936.

3. Casper Höweler, Inleiding tot de muziekgeschiedenis.

4. Gilbert (W. G.), Een en ander over de negroide muziek van Suriname 1940.

5. H. C. Focke, „De Surinaamsche negermuzijk”. Tijdschrift WestIndië, 2e dl, 1858, blz. 93-107.

6. R. D. Teenstra, De landbouw in de kolonie Suriname, 2e dl. 1835.

7. Catalogus der Afd. Ned. Koloniën. Tentoonstelling A'dam 1883, blz. 296.

8. Encyclopaedie van Nederlandsch West-Indië. 's-Gravenhage, 19141917. 

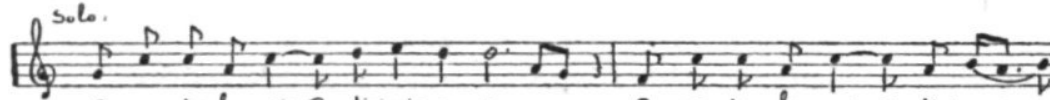

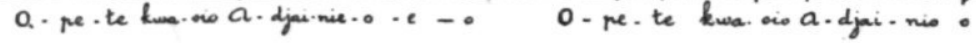

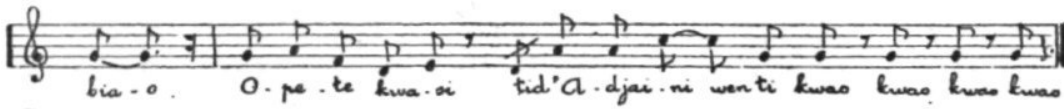

Xoor:

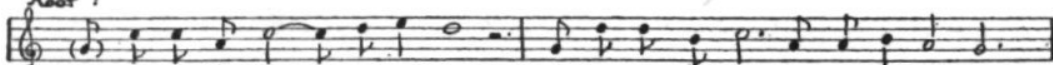

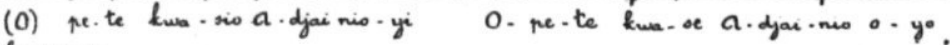
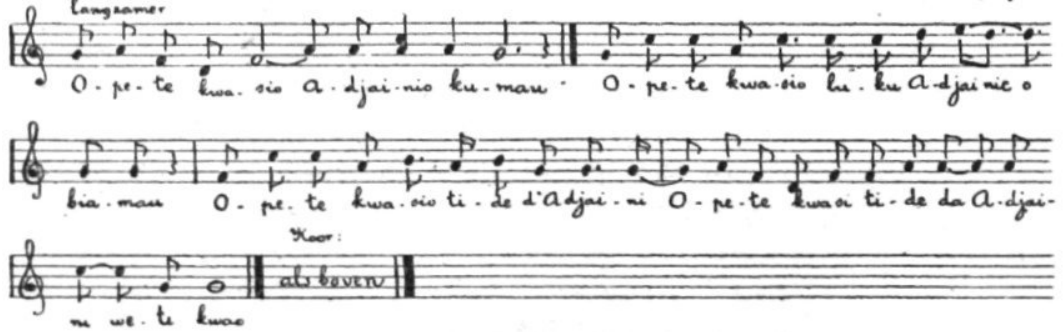

ENGELSCHE TEKST

Tell all the women for me

I am not dead yet;

Tell all the women for me,

I live, I am not dead.

But let go of my neck,

And clasp my back;

When I am in my hour of passion,

Loosen my head.

Hold me by the neck,

Loosen my back,

When I am in my hour of pleasure,

Loosen my neck.

Uit: Melville J. Herskovits and Fr. S. Herskovits, Suriname Folklore, blz. 640 . 
Voorbeeld van Stadsnegermuziek Adyanti winti
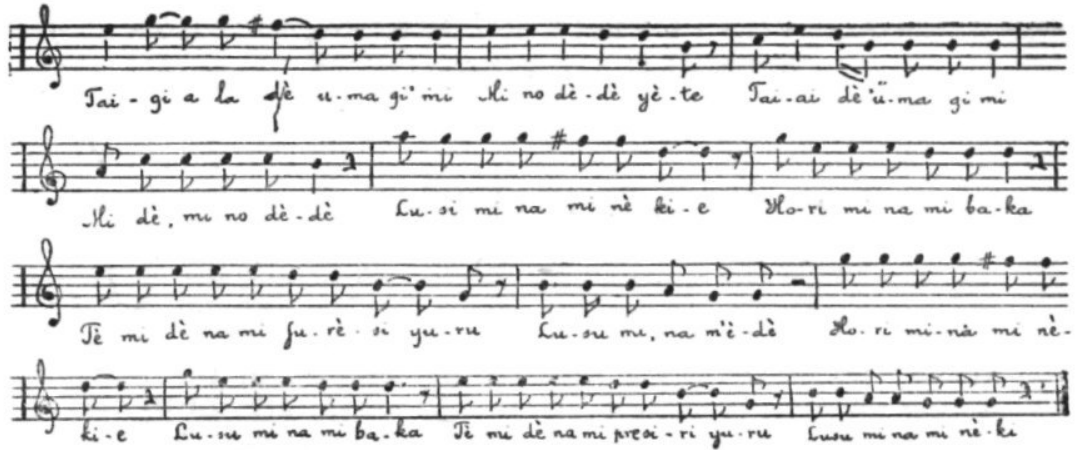

ENGELSCHE TEKST

,,Sunday Vulture, O mighty one, Sunday Vulture, O mighty spirit of magic, Sunday Vulture, today the mighty winti Kwao, Kwao, Kwao. [Said to be call of the vulture.] Sunday Vulture, O mighty one, greetings. Sunday Vulture, look at the mighty obiaman".

Uit: Melville J. Herskovits and Fr. S. Herskovits, Suriname Folklore, blz. 546 . 